\title{
Water soluble gel lubricant on vaginal speculums had no effect on cervical cytology results
}

\author{
Amies AM, Miller L, Lee SK, et al. The effect of vaginal speculum lubrication on the rate of unsatisfactory cervical cytology
} diagnosis. Obstet Gynecol 2002;100:889-92.

\section{QUESTION: In women having Papanicolaou (Pap) smears, does the application of water soluble gel lubricant to the plastic vaginal speculum change the rate of unsatisfactory cervical cytology diagnosis?}

\section{Design}

Cluster randomised \{allocation concealed $*$ †, blinded (outcome assessors),* controlled trial.

\section{Setting}

5 public health family planning clinics in Seattle, Washington, USA.
Source of funding:

National Institutes of

Health.

For correspondence:

Dr A M Amies,

University of

Washington Medical

Center, Seattle, WA,

USA.

aamies@

u.washington.edu

\section{Patients}

2906 women of reproductive age (mean age 23 y) undergoing cervical cytology specimen collection. All patients were included in the analysis.

\section{Intervention}

Patients were allocated to water soluble gel lubricant (water, propylene glycol, hydroxpropyl methylcellulose, carbomer 934P, methylparaben, propylparaben, and
Lubrication v no lubrication for speculums in Papanicolaou smears $\ddagger$

\begin{tabular}{lllll} 
Outcome & Lubrication & $\begin{array}{l}\text { No } \\
\text { lubrication }\end{array}$ & RRI $(95 \%$ Cl) & NNH \\
$\begin{array}{l}\text { Unsatisfactory } \\
\text { cytology diagnosis }\end{array}$ & $1.4 \%$ & $1.3 \%$ & $7.2 \%(-42$ to 98$)$ & Not significant \\
\hline
\end{tabular}

†Abbreviations defined in glossary; RRI, $\mathrm{NNH}$, and $\mathrm{Cl}$ calculated from data in article. sodium hydroxide) $(\mathrm{n}=1440)$ or no lubricant except tap water $(n=1466)$ for all speculum examinations for cervical cytology specimen collection.

\section{Main outcome measures}

The main outcome measure was unsatisfactory cytology diagnoses. Other cervical cytology results included atypical squamous cells of undetermined significance [ASCUS], low grade squamous intraepithelial lesion [LGSIL], high grade SIL [HGSIL], atypical glandular cells of undetermined significance [AGCUS], and atypical endometrial cells.

\section{Main results}

The intervention and control groups did not differ for the primary outcome (table) or for other cytology results.

\section{Conclusion}

In women having Papanicolaou smears, application of water soluble gel lubricant to the plastic vaginal speculum had no effect on the rate of unsatisfactory cervical cytology diagnoses.

*See glossary.

$\uparrow$ Information provided by author.

\section{COMMENTARY}

A few years ago, a senior resident challenged me to produce evidence that vaginal lubricant interfered with cervical cytology results. My literature searches yielded no reports, even though I had been taught not to use lubricant when obtaining a Pap smear because it could affect the quality of the smear. At last, 2 studies have addressed this clinical question. Amies $\mathrm{et} \mathrm{al} \mathrm{randomised} 5$ family planning clinics to use vaginal lubricant or tap water on the speculum, and found no difference in the rate of unsatisfactory smears. This study had more than $80 \%$ power to detect a doubling of the rate of unsatisfactory smears ( $\mathrm{p}<0.05$ ), so an increase in the rate of unsatisfactory smears would not have been missed. Harer et al randomised 182 women at a single health clinic to vaginal lubricant or tap water, and also found low rates of unsatisfactory Pap smears with no difference between the 2 groups. Although this study had only $70 \%$ power to find a difference of $5 \%$ in the rate of unsatisfactory smears, the results were consistent with those of Amies et al.

Another teaching that remains with me from medical school is that vaginal lubricant is bacteriostatic and thus interferes with the accuracy of cultures for gonorrhoea or chlamydia. This question is clinically important because sexually transmitted diseases and cervical cancer screening are often done in concert. Evidence on this point is limited, and in vitro studies suggest that further research is needed. ${ }^{1}$ DNA probes are often done instead of cultures for screening. A single small study suggests that lubricant is unlikely to have a large effect on chlamydia polymerase chain reaction sensitivity. However, a reduction in sensitivity of $10-20 \%$ could not be ruled out. ${ }^{2}$ Further research is needed to answer these questions definitively. 


\title{
Lubrication of the vaginal introitus and external speculum had no effect on Papanicolaou smear interpretation
}

\author{
Harer WB, Jr, Valenzuela G, Lebo D. Lubrication of the vaginal introitus and speculum does not affect Papanicolaou \\ smears. Obstet Gynecol 2002;100:887-8.

\section{QUESTION: In women having Papanicolaou smears, does lubrication of the vaginal introitus and external speculum affect cervical cytology results?}

\section{Design}

Randomised (allocation concealed*), blinded (outcome assessors), ${ }^{*}$ controlled trial.

\section{Setting}

Arrowhead Regional Medical Center Women's Health Clinic, Colton, California, USA.

\section{Patients}

182 women (mean age 35 y) who presented to the clinic for Papanicolaou smears. Patients with known untreated cervical cancer or active bleeding were excluded. All patients were included in the analysis.

\section{Intervention}

Patients were allocated to 2-3 cc surgilube (water soluble lubricant) on the gloved fingers before insertion of an externally lubricated speculum $(\mathrm{n}=93)$ or no lubricant other than water on the speculum $(\mathrm{n}=89)$.

\section{Main outcome measure}

The main outcome measure was an unsatisfactory

Papanicolaou smear result.

\section{Main results}

The groups did not differ for the primary outcome Source of funding: (table).

\section{Conclusion}

In women having Papanicolaou smears, lubrication of the vaginal introitus and external speculum did not affect cervical cytology results.

*See glossary. not stated.

For correspondence: Dr W B Harer Jr, Riverside Regional Medical Center, Moreno Valley, $C A$, USA.

bharer@ coriverside.ca.us

\begin{tabular}{|c|c|c|c|c|}
\hline Outcome & Lubrication & No lubrication & RRR (95\% CI) & NNT \\
\hline $\begin{array}{l}\text { Unsatisfactory } \\
\text { Papanicolaou } \\
\text { smear }\end{array}$ & $2.1 \%$ & $2.2 \%$ & $4.3 \%(-43$ to 83$)$ & Not significant \\
\hline
\end{tabular}

†Abbreviations defined in glossary; RRR, NNT, and $\mathrm{Cl}$ calculated from data in article.

\section{COMMENTARY - continued from previous page}

Enhancing the comfort of women having speculum examinations is important for both quality of care and public health. More than $50 \%$ of women diagnosed with cervical cancer have never been screened or have not had a Pap smear in the previous 3 years. ${ }^{3}$ Less discomfort associated with the exam may increase the likelihood that women return for screening at regular intervals. Kudos to Doctors Amies and Harer for addressing this small but important aspect of clinical practice. Their findings have changed my practice and should change the practice of others as well. Patient comfort during Pap smears will affect compliance and may ultimately improve our ability to prevent mortality from cervical cancer.

1 Holliman RE, Johnson JD, Davidson F. Inhibition of Neisseria gonorrhoeae by vaginal lubricants. Sex Transm Infect 2002;78:468.

Uribasterra P, Creinin MD, Wiesenfeld HC. Does digital vaginal examination using lubricant have an impact on testing for Chlamydia trachomatis by polymerase chain reaction? Sex Transm Dis 2002;29:112-3.

3 Sung HY, Kearney KA, Miller M, et al. Papanicolaou smear history and diagnosis of invasive cervical carcinoma among members of a large prepaid health plan. Cancer 2000;88:2283-9. 